\title{
GAMBARAN PENOLAKAN MASYARAKAT \\ TERHADAP PUNGSI LUMBAL DI BAGIAN NEUROLOGI BLU RSUP. PROF. DR. R.D. KANDOU MANADO
}

\author{
Selvyani Pasomba \\ Herlyani Khosama \\ Junita M. P. Sampoerno \\ Bagian Neurologi Fakultas Kedokteran Universitas Sam Ratulangi Manado \\ Email: selvyani_pasomba@yahoo.com
}

\begin{abstract}
The examination of cerebrospinal fluid obtained by a lumbar puncture is important in the diagnosis of CNS infection. There have been no reports of refusals of lumbar punctures in Manado. This study is a descriptive preliminary using interviews and questionnaires. The subjects were all patients or families of patients in the inpatient unit at the Department of Neurology BLU. Prof. Dr. R. D. Kandou Manado in November 2012. The results showed that of the total number of 60 respondents, $27(45 \%)$ under advice, agreed to undergo lumbar punctures; $30(50 \%)$ refused, and $3(5 \%)$ were not able to decide and thus abstained. While $93.3 \%$ of respondents knew the definition and indications of lumbar puncture, $86.7 \%$ refused eventhough they knew that the lumbar puncture procedure was important in the management of the disease; $86.7 \%$ assumed that the lumbar puncture was a dangerous procedure; $80 \%$ felt unsure enough to refuse; and $86.7 \%$ were afraid to have the lumbar puncture procedure done. All respondents knew that lumbar puncture had complications. Conclusion: nearly all respondents who refused knew that the lumbar puncture procedure is important in the management of the disease, yet they assumed the lumbar puncture was dangerous, uncomfortable, and felt fearful.
\end{abstract}

Keywords: lumbar puncture, neurology, refusal description, society.

\begin{abstract}
Abstrak: Pemeriksaan cairan serebrospinal yang diperoleh melalui tindakan pungsi lumbal penting untuk mendiagnosis infeksi susunan saraf pusat. Meskipun demikian, sering terjadi penolakan terhadap pemeriksaan ini. Sampai saat ini belum ada laporan tentang gambaran penolakan pungsi lumbal di Manado. Penelitian ini bersifat deskriptif dengan wawancara menggunakan kuesioner. Subjek penelitian ialah semua pasien atau keluarga pasien di ruang rawat inap Bagian Neurologi BLU RSUP. Prof. Dr. R.D. Kandou Manado bulan November 2012. Hasil penelitian memperlihatkan jumlah responden sebanyak 60 orang, 27 (45\%) setuju jika seandainya disarankan untuk menjalani pungsi lumbal, 30 (50\%) menolak, dan tiga (5\%) tidak dapat memutuskan setuju atau menolak (abstain). Sebanyak 93,3\% responden mengetahui definisi dan indikasi pungsi lumbal, $86,7 \%$ responden yang menolak menganggap pungsi lumbal penting dalam penatalaksanaan penyakit, $86,7 \%$ menganggap pungsi lumbal merupakan tindakan yang berbahaya, $80 \%$ responden merasa tidak nyaman, dan $86,7 \%$ takut terhadap pungsi lumbal. Simpulan: hampir seluruh responden yang menolak mengetahui bahwa tindakan pungsi lumbal penting dalam penatalaksanaan penyakit, dan menganggap pungsi lumbal sebagai tindakan berbahaya, tidak nyaman dan merasa takut pada tindakan ini.

Kata kunci: pungsi lumbal, neurologi, gambaran penolakan, masyarakat.
\end{abstract}


Infeksi susunan saraf pusat (SSP) telah lama dikenal sebagai penyakit berbahaya yang dapat berkembang cepat dan menyebabkan kerusakan berat, bahkan kematian jika tidak dikenali dan ditangani segera. ${ }^{1}$ Infeksi SSP dapat dibedakan menurut lokasi utama terjadinya peradangan, yaitu: meningitis, araknoiditis, ensefalitis, mielitis, atau kombinasi (ensefalomielitis, meningoensefalitis). ${ }^{2}$

Jenis infeksi SSP yang paling umum ialah meningitis akut yang disebabkan virus sedangkan bentuk yang paling parah ialah meningitis bakterialis akut. ${ }^{1}$ Berdasarkan laporan dari Center for Disease Control (CDC) di Amerika Serikat, kejadian meningitis karena virus cukup besar yaitu 11 per 100.000 penduduk per tahun. Selain itu, meningitis bakterialis akut saat ini menjadi ancaman serius bagi kesehatan global karena diperkirakan terjadi 170 ribu kematian di seluruh dunia akibat penyakit ini. ${ }^{3,4}$

Infeksi SSP khususnya meningitis, merupakan masalah yang serius sehingga dibutuhkan cara yang akurat dan efisien untuk menegakkan diagnosis. Pemeriksaan fisik saja tidak cukup untuk mendiagnosis meningitis secara akurat; untuk itu dibutuhkan analisis cairan serebrospinal (CSS) yang diperoleh melalui tindakan pungsi lumbal untuk memperkuat diagnosis. ${ }^{5}$ Informasi yang dihasilkan melalui pemeriksaan cairan serebrospinal sangat penting dan bernilai sebagai alat bantu diagnostik dalam mengevaluasi kondisi peradangan, perdarahan sub-araknoid, serta penyakit yang memengaruhi tekanan intrakranial. ${ }^{6}$

Pungsi lumbal adalah tindakan yang dilakukan untuk memperoleh CSS serta untuk mengetahui keadaan lintasan cairan tersebut. ${ }^{7}$ Sejak diperkenalkan pada tahun 1890, pungsi lumbal telah menjadi pemeriksaan neuro-diagnostik yang sering dilakukan di bidang neurologi. Hal ini disebabkan karena kebutuhan untuk pengambilan CSS serta pengukuran tekanan pembukaan untuk diagnosis banding dan tidak lanjut terhadap pemantauan penyakit infeksi pada sistem saraf. ${ }^{8}$ Selain indikasi diagnostik, pungsi lumbal juga mempunyai indikasi terapeutik misalnya kemoterapi intratekal untuk penyakit keganasan, mengurangi CSS pada hipetensi intrakranial jinak, setelah pembedahan saraf, serta pada anestesi spinal. ${ }^{9}$ Pungsi lumbal dilakukan setelah dilakukan pemeriksaan neurologi secara keseluruhan untuk meminimalisasi risiko tindakan. $^{10}$

Meskipun pungsi lumbal merupakan tindakan yang penting dan relatif aman, namun ternyata terdapat penolakan yang cukup besar terhadap tindakan ini oleh masyarakat. Pada studi kualitatif yang dilakukan di Uni Emirat Arab didapatkan bahwa dari 55 keluarga yang diminta persetujuan untuk dilakukan pungsi lumbal pada anak mereka, 24 (44\%) di antaranya menolak; tujuh orang (29\%) merasa asing dengan pemeriksaan pungsi lumbal; 18 orang $(75 \%)$ takut terhadap komplikasi yang bisa ditimbulkan setelah pemeriksaan pungsi lumbal; dan lima orang (21 \%) merasa bahwa pungsi lumbal tidak perlu dilakukan. $^{11}$

Pada penelitian di Singapura oleh Ling dan Boey tentang penolakan pungsi lumbal pada kasus-kasus kejang demam, didapatkan dari 77 kasus yang diindikasikan untuk pemeriksaan pungsi lumbal, 19 pasien (25\%) menolak menjalani pemeriksaan. Masyarakat tempat penelitian terdiri dari beberapa etnis yaitu Melayu, Cina, dan India. Setiap etnis memiliki sosio-budaya tersendiri serta cara pandang berbeda terhadap pungsi lumbal yang berpengaruh terhadap keputusan untuk menerima atau menolak pemeriksaan pungsi lumbal. ${ }^{12}$

Di Indonesia termasuk kota Manado, belum pernah dipublikasikan di media ilmiah nasional atau internasional yang membahas tentang penolakan pungsi lumbal pada kasus neurologi, sehingga informasi mengenai hal-hal yang mempengaruhi penolakan tersebut belum diketahui.

\section{METODE PENELITIAN}

Penelitian ini merupakan suatu penelitian pendahuluan yang bersifat deskriptif dengan metode wawancara menggunakan kuesioner. Penelitian ini dilaksanakan selama satu bulan, yaitu pada bulan November 
2012. Subjek penelitian ialah semua pasien atau keluarga pasien di ruang rawat inap Bagian Neurologi BLU RSUP Prof. Dr. R. D. Kandou Manado bulan November 2012.

Kriteria inklusi ialah semua subjek penelitian, sedangkan criteria eksklusi ialah pasien atau keluarganya yang setuju dengan pungsi lumbal tetapi tidak mampu mengisi kuesioner.

Variabel penelitian terdiri dari: usia, jenis kelamin, pendidikan terakhir, pengetahuan tentang pungsi lumbal, dan sikap terhadap pungsi lumbal.

Pengolahan data dalam penelitian ini menggunakan SPSS versi 20, untuk mendeskripsikan variabel penelitian dalam bentuk distribusi frekuensi.

\section{HASIL}

\section{Jumlah Responden}

Jumlah responden yang bersedia diwawancara sebanyak 60 orang. Sebanyak $27(45 \%)$ responden setuju jika seandainya disarankan untuk menjalani pungsi lumbal; $30(50 \%)$ menolak, dan $3(5 \%)$ tidak dapat memutuskan setuju atau menolak (abstain) (Gambar 1).

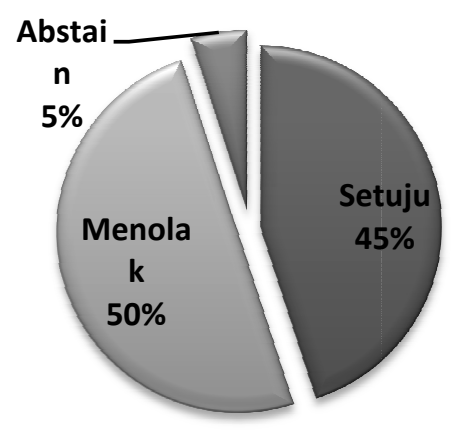

Gambar 1. Sebaran responden berdasarkan sikap terhadap tindakan pungsi lumbal.

\section{Karakteristik responden yang menolak tindakan}

\section{Distribusi responden berdasarkan jenis kelamin}

Dari 30 responden yang menolak, 25 $(83,3 \%)$ berjenis kelamin perempuan.

\section{Distribusi responden berdasarkan usia}

Responden yang menolak tindakan pungsi lumbal sebagian besar berada pada kelompok usia 41-50 tahun (Tabel 1).

Tabel 1. Distribusi responden berdasarkan usia

\begin{tabular}{ccc}
\hline $\begin{array}{c}\text { Usia } \\
\text { (tahun) }\end{array}$ & $\begin{array}{c}\text { Frekuensi } \\
(\mathbf{n})\end{array}$ & $\begin{array}{c}\text { Persentase } \\
(\mathbf{\%})\end{array}$ \\
\hline $20-30$ & 7 & 23,3 \\
$31-40$ & 5 & 16,7 \\
$41-50$ & $\mathbf{1 2}$ & $\mathbf{4 0 , 0}$ \\
$51-60$ & 6 & 20,0 \\
Total & 30 & 100,0 \\
\hline
\end{tabular}

\section{Distribusi responden berdasarkan pendidikan}

Responden yang menolak tindakan pungsi lumbal terbanyak berlatar belakang pendidikan SMA/sederajat (Tabel 2).

Tabel 2. Distribusi responden berdasarkan pendidikan.

\begin{tabular}{ccc}
\hline $\begin{array}{c}\text { Pendidikan } \\
\text { terakhir }\end{array}$ & $\begin{array}{c}\text { Frekuensi } \\
(\mathbf{n})\end{array}$ & $\begin{array}{c}\text { Persentase } \\
(\mathbf{\%})\end{array}$ \\
\hline SD & 7 & 23,3 \\
SMP & 7 & 23,3 \\
SMA (sederajat) & $\mathbf{1 3}$ & $\mathbf{4 3 , 3}$ \\
D1-D3 & 2 & 6,7 \\
S1 & 1 & 3,3 \\
Total & 30 & 100,0 \\
\hline
\end{tabular}

\section{Pengetahuan Responden}

Pengetahuan responden tentang tindakan pungsi lumbal diperlihatkan pada Tabel 3.

Dari Tabel 3 terlihat bahwa hampir semua responden mengetahui bahwa pungsi lumbal merupakan tindakan mengambil cairan otak dan memiliki manfaat dalam mendiagnosis penyakit di susunan saraf pusat, namun hanya $36,7 \%$ yang mengetahui bahwa salah satu indikasi pungsi lumbal ialah bayi yang demam tanpa sebab yag jelas. Seluruh responden mengetahui bahwa terdapat komplikasi dari tindakan pungsi lumbal. Sebagian besar responden belum 
pernah mendengar tentang pungsi lumbal baik dari keluarga maupun orang yang pernah menjalani tindakan ini.

\section{Sikap responden}

Hasil penelitian mengenai sikap responden terhadap pungsi lumbal diuraikan pada Tabel 4.

Sebanyak $86,7 \%$ responden menganggap pungsi lumbal sebagai tindakan berbahaya dan seluruh responden menolak jika dirinya disarankan menjalani tindakan pungsi lumbal. Namun demikian, 86,7\% responden mengetahui bahwa tindakan pungsi lumbal penting dalam penatalaksanaan penyakit. Sebagian besar responden merasa tidak nyaman (80\%) dan takut $(86,7 \%)$ terhadap tindakan pungsi lumbal. Tidak ada responden yang menyatakan bahwa budaya, adat istiadat, atau agama melarang pungsi lumbal.

Tabel 3. Distribusi pengetahuan responden tentang pungsi lumbal.

\begin{tabular}{lccc}
\hline \multicolumn{1}{c}{ Pengetahuan responden } & $\begin{array}{c}\text { Benar/Ada/Pernah } \\
(\mathbf{\%})\end{array}$ & $\begin{array}{c}\text { Salah/Tidak } \\
(\mathbf{\%})\end{array}$ & $\begin{array}{c}\text { Total } \\
\mathbf{( \% )}\end{array}$ \\
\hline $\begin{array}{l}\text { Pengertian tentang pungsi lumbal } \\
\text { sebagai tindakan untuk mengambil } \\
\text { cairan otak }\end{array}$ & $28(93,3 \%)$ & $2(6,7 \%)$ & $30(100 \%)$ \\
$\begin{array}{l}\text { Pungsi lumbal sebagai cara menen- } \\
\text { tukan diagnosis penyakit di SSP }\end{array}$ & $23(76,7 \%)$ & $7(23,3 \%)$ & $30(100 \%)$ \\
$\begin{array}{l}\text { Pungsi lumbal sebagai cara men- } \\
\text { deteksi penyakit radang pada susun- }\end{array}$ & $27(90 \%)$ & $3(10 \%)$ & $30(100 \%)$ \\
$\begin{array}{l}\text { an saraf pusat } \\
\text { Pungsi lumbal sebagai cara menen- } \\
\text { tukan penyakit radang pada selaput } \\
\text { otak }\end{array}$ & $26(86,7 \%)$ & $4(13,3 \%)$ & $30(100 \%)$ \\
$\begin{array}{l}\text { Pungsi lumbal dapat dilakukan pada } \\
\text { bayi yang demam tanpa sebab }\end{array}$ & $11(36,7 \%)$ & $19(63,3 \%)$ & $30(100 \%)$ \\
$\begin{array}{l}\text { Pungsi lumbal mempunyai kom- } \\
\text { plikasi }\end{array}$ & $30(100 \%)$ & $0(0 \%)$ & $30(100 \%)$ \\
$\begin{array}{l}\text { Tindakan prosedur yang tepat dan } \\
\text { teliti dapat mencegah komplikasi } \\
\text { pungsi lumbal }\end{array}$ & $27(90 \%)$ & $3(10 \%)$ & $30(100 \%)$ \\
$\begin{array}{l}\text { Ada tidaknya keluarga yang pernah } \\
\text { menjalani pemeriksaan pungsi } \\
\text { lumbal }\end{array}$ & $4(13,3 \%)$ & $26(86,7 \%)$ & $30(100 \%)$ \\
$\begin{array}{l}\text { Pernah tidaknya mendengar pungsi } \\
\text { lumbal }\end{array}$ & $5(16,7 \%)$ & $25(83,3 \%)$ & $30(100 \%)$ \\
$\begin{array}{l}\text { Pernah tidaknya mendengar cerita } \\
\text { orang lain yang pernah menjalani } \\
\text { pungsi lumbal }\end{array}$ & $6(20 \%)$ & $24(80 \%)$ & $30(100 \%)$ \\
$\begin{array}{l}\text { Pernah tidaknya mendengar cerita } \\
\text { yang tidak baik tentang pungsi } \\
\text { lumbal }\end{array}$ & $7(23,3 \%)$ & $23(76,7 \%)$ & $30(100 \%)$ \\
$\begin{array}{l}\text { Ada tidaknya komplikasi pungsi } \\
\text { lumbal yang diketahui responden }\end{array}$ & $4(13,3 \%)$ & $26(86,7 \%)$ & $30(100 \%)$ \\
\hline
\end{tabular}


Tabel 4. Distribusi sikap responden terhadap pungsi lumbal.

\begin{tabular}{|c|c|c|c|}
\hline Sikap Responden & $\begin{array}{l}\text { Ada/Ya/ } \\
\text { Penting/ } \\
\text { Menerima/ } \\
\text { Nyaman } \\
(\%)\end{array}$ & $\begin{array}{c}\text { Tidak/Tidak } \\
\text { Penting/ } \\
\text { Menolak/ } \\
\text { Tidak } \\
\text { Nyaman (\%) }\end{array}$ & Total \\
\hline Pungsi lumbal sebagai tindakan yang berbahaya & $26(86,7 \%)$ & $4(13,3 \%)$ & $30(100 \%)$ \\
\hline $\begin{array}{l}\text { Pungsi lumbal penting terhadap pengobatan } \\
\text { penyakit pasien }\end{array}$ & $25(86,7 \%)$ & $5(13,3 \%)$ & $30(100 \%)$ \\
\hline Jika disarankan menjalani pungsi lumbal & 0 & $30(100 \%)$ & $30(100 \%)$ \\
\hline $\begin{array}{l}\text { Kenyamanan responden terhadap pemeriksaan } \\
\text { pungsi lumbal }\end{array}$ & $6(20 \%)$ & $24(80 \%)$ & $30(100 \%)$ \\
\hline $\begin{array}{l}\text { Rasa takut responden untuk menjalani pungsi } \\
\text { lumbal }\end{array}$ & $26(86,7 \%)$ & $4(13,3 \%)$ & $30(100 \%)$ \\
\hline $\begin{array}{l}\text { Ada tidaknya budaya, adat istiadat, agama yang } \\
\text { melarang pungsi lumbal }\end{array}$ & 0 & $30(100 \%)$ & $30(100 \%)$ \\
\hline
\end{tabular}

\section{BAHASAN}

Penelitian ini merupakan penelitian pendahuluan yang dilakukan tanpa desain sampel, dan tidak dilakukan khusus pada pengambil keputusan untuk persetujuan tindakan pungsi lumbal. Dari penelitian ini didapatkan jumlah pasien atau keluarga pasien yang bersedia diwawancara sebanyak 60 orang. Rasio antara yang setuju dan menolak tindakan pungsi lumbal berimbang yaitu 45:50. Temuan ini secara umum mengindikasikan masih tingginya penolakan masyarakat terhadap tindakan pungsi lumbal.

Responden yang didapatkan perempuan (83\%) lebih banyak dibandingkan lakilaki. Hal ini mungkin disebabkan sebagian besar responden yang diwawancarai memang berjenis kelamin perempuan.

Secara umum, semakin dewasa seseorang, dia akan menjadi lebih bijaksana, berani bertanggung jawab dan mengambil keputusan penting, berpikir rasional, mengendalikan emosi, dan bertoleransi terhadap pandangan orang lain. ${ }^{13}$ Pada penelitian ini sebagian besar responden yang menolak berusia $>40$ tahun. Hal ini meng-indikasikan bahwa lebih banyak pandangan negatif yang diterima pasien/ keluarga pasien mengenai pungsi lumbal seiring dengan pertambahan usia, yang berperan dalam penolakan tindakan..
Latar belakang pendidikan responden yang menolak sebagian besar SMA atau lebih rendah. Hal ini mungkin disebabkan bahwa rendahnya pendidikan cenderung membuat seseorang akan lebih mempercayai pendapat masyarakat awam dibandingkan pendapat medis. Dengan demikian bila penjelasan medis mengenai tindakan pungsi lumbal diberikan pada masyarakat yang berlatar belakang pendidikan rendah maka mereka lebih cenderung menolak bila terdapat pandangan awam yang bertentangan dengan hal tersebut.

Tabel 3 menjelaskan bahwa terdapat 93,3\% responden menyatakan benar bahwa pungsi lumbal sebagai tindakan untuk menggambil cairan otak melalui tulang belakang. Selain itu, sebanyak 76,7\% responden menyatakan benar bahwa pungsi lumbal sebagai cara menentukan diagnosis suatu penyakit di SSP. Hasil ini menunjukkan hampir semua responden telah mengetahui pengertian pungsi lumbal. Hal ini mirip dengan penelitian Hassib et al. yang melaporkan hanya $29 \%$ subyek yang tidak mengetahui tentang pungsi lumbal. ${ }^{11}$

Sebanyak 63,3\% responden tidak mengetahui bahwa pungsi lumbal dapat dilakukan pada bayi yang demam tanpa penyebab yang jelas. Hal ini tentu dapat mempengaruhi penolakan mereka terhadap tindakan pungsi lumbal pada anak mereka, 
seperti yang dikemukakan dalam penelitian Ling dan Boey. ${ }^{12}$ Oleh karena itu, cakupan indikasi pungsi lumbal pada anak perlu mendapat perhatian khusus.

Semua responden mengetahui bahwa pungsi lumbal memiliki komplikasi. Disamping itu sebanyak $90 \%$ responden menyatakan benar bahwa jika pungsi lumbal dilakukan dengan tepat dan teliti dapat mencegah komplikasi. Hal ini berbeda dengan penelitian Hassib et al. yang mengemukakan hanya $37 \%$ subyek yang mengetahui komplikasi pungsi lumbal. ${ }^{11}$ Hal ini mungkin disebabkan perbedaan desain kuesioner.

Penjelasan mengenai komplikasi perlu disampaikan secara rinci karena secara umum responden telah mengetahui adanya komplikasi akibat tindakan pungsi lumbal. Hasil penelitian memperlihatkan $90 \%$ responden setuju jika pungsi lumbal dilakukan dengan tepat dan teliti dapat mencegah komplikasi. Alasan penolakan mungkin akibat adanya keraguan apakah prosedur yang dilakukan tepat dan teliti.

Hasil penelitian memperlihatkan $86,7 \%$ responden mengganggap pungsi lumbal sebagai tindakan yang berbahaya. Selain itu, $80 \%$ responden merasa tidak nyaman dengan tindakan ini dan $86,7 \%$ merasa takut untuk menjalani pungsi lumbal. Hal ini sebagian mirip dengan hasil penelitian Hassib et al. yang melaporkan beberapa alasan utama terjadinya penolakan pungsi lumbal antara lain: takut akan komplikasi yang akan terjadi setelah tindakan ini dilakukan, persepsi bahwa pungsi lumbal tidak penting untuk dilakukan, dan adanya rasa ketidakpercayaan pasien terhadap dokter. ${ }^{11}$

Sebanyak 86,7\% memahami pungsi lumbal penting untuk pengobatan penyakit. Hal ini berbeda dengan penelitian Hassib et al. yang menemukan banyak responden yang menolak oleh karena menganggap tindakan ini tidak penting. ${ }^{11}$ Pemahaman responden ini tentu bertentangan dengan sikap penolakan mereka; hal ini menunjukkan kemungkinan adanya alasan lain yang mendasari penolakan.
Alasan penolakan yang ditemukan sebagian besar mirip dengan penelitianpenelitian lain yaitu keyakinan bahwa tindakan pungsi lumbal itu berbahaya, rasa takut, dan rasa tidak nyaman. Alasan ketidaktahuan atau karena menganggap tidak penting tidak banyak ditemukan dalam penelitian. ${ }^{11,12}$

Hal yang menarik ialah semua responden menyatakan tidak terdapat pengaruh budaya, adat istiadat, atau agama yang melarang pengambilan cairan otak. Temuan ini berbeda dengan penelitian Ling dan Boey terhadap respoden yang mencakup tiga kelompok etnis yaitu Cina, India, dan Melayu. Ling dan Boey melaporkan bahwa terdapat hubungan yang bermakna antara penolakan pungsi lumbal pada kelompok etnis Melayu. Pengaruh budaya dan kepercayaan etnis Melayu di Singapura menyebabkan masyarakat takut dan menolak tindakan pungsi lumbal. ${ }^{12} \mathrm{Hal}$ demikian tidak ditemukan dalam penelitian ini sehingga pendekatan budaya tidak begitu penting dalam edukasi masyarakat disini; yang lebih penting ialah membangun kepercayaan masyarakat tentang keamanan tindakan dan keterampilan tenaga medis.

\section{SIMPULAN}

1. Jumlah yang setuju dan menolak tindakan pungsi lumbal berimbang.

2. Sebagian responden yang menolak tindakan paling banyak berasal dari kelompok umur $\geq 41$ tahun dan berlatar belakang pendidikan SMA atau sederajat.

3. Sebagian besar responden yang menolak mengetahui secara umum mengenai tindakan pungsi lumbal sebagai tindakan untuk mengambil cairan otak dan cara mendeteksi adanya penyakit radang di SSP.

4. Sebagian besar responden yang menolak menganggap pungsi lumbal penting dalam penatalaksanaan penyakit.

5. Seluruh responden yang menolak mengetahui bahwa pungsi lumbal memiliki komplikasi. 
6. Sebagian besar responden yang menolak menganggap pungsi lumbal sebagai tindakan yang berbahaya, menakutkan dan tidak nyaman.

\section{UCAPAN TERIMA KASIH}

Ucapan terima kasih ditujukan kepada dr. Arhtur H.P. Mawuntu, SpS selaku penguji I, dan Dr. Denny J. Ngantung, SpS selaku peng-uji II, serta semua pihak yang secara langsung dan tidak langsung telah menumbuhkan ide atau gagasan sehingga penulis dapat menyelesaikan tulisan ini.

\section{DAFTAR PUSTAKA}

1. Pokorn M. Pathogenesis and classification of central nervous system infection. JIFCC. 2003;15:3.

2. Somand D, Meurer W. Central nervous system infections. Emerg Med Clin. 2009;27.89.

3. Wan C, Roos LK. Viral meningitis [homepage on the Internet]. 29 Maret 2011 [cited 2012 Oct 08]. Available from: http://emedicine.medscape.com/article/116 8529-overview\#a0156

4. World Health Organization. Bacterial Meningitis [homepage on the Internet]. Februari 2012 [cited 2012 Oct 08]. Available from: http://www.who.int/nuvi/meningitis/en/ind ex.html

5. Fitch TM. Focus on: meningitis-beyond fever,stiff neck,and altered mental status [homepage on the Internet]. April 2007 [cited 2012 Oct 08]. Available from:http://www.acep.org/content.aspx?id $=26464$

6. Ropper HA, Samuels A M. Adams and victor's principles of neurology (Ninth Edition). New York: McGraw-Hill, 2009; p.13.

7. Mardjono M, Sidharta P. Neurologi klinis dasar. Jakarta: Dian rakyat, 2008; p.416.

8. Strasse HK. Lumbar puncture with the sprotte ${ }^{\circledR}$ cannula-for safe diagnostics [homepage on the Internet]. 2009 (cited 2012 Aug 20]. Available from: http://www.pajunk.com

9. Moghtaderi A, Naini A R, Sanatinia S. Lumbar puncture: techniques, complications and CSF analyses. Emergency Medicine - An International Perspective [homepage on the Internet]. Maret 2012 [diakses tanggal 20 Oktober 2012]. Available from: http://www.intechopen.com/books/emerge ncy-medicine-aninternationalperspective/lumbar-puncture-techniquescomplications-and-csf-analyses

10. Fong B, VanBendegon MJ. Lumbar puncture. Mac1113. 2003;122:859-77

11. Narchi H, Ghatasheh G, Hassani AN, Reyami AL, Khan Q. Why do some parents refuse consent for lumbar puncture on their child? a qualitative study. Hospital pediatrics. 2012;2:93-100

12. Ling GS, Boey MCC. Lumbar puncture refusal in febrile convulsion. Singapore med j. 2000;41(10):485-88

13. Sukaesih F. Hubungan karakteristik petugas dengan kinerja petugas rekam medik di rumah sakit umum daerah Rokan Hulu [Tesis]. Sumatera Utara: Universitas Sumatera Utara;2008. 